\title{
INDONESIA DI PERSIMPANGAN: URGENSI "UNDANG-UNDANG KESETARAAN DAN KEADILAN GENDER" DI INDONESIA PASCA DEKLARASI BERSAMA BUENOS AIRES PADA TAHUN 2017
}

(Indonesia at a Crossroads: The Urgency of "Gender Equality and Justice Act" in Indonesia After Buenos Aires Joint Declaration in 2017)

\author{
Indra Kusumawardhana \\ Program Studi Hubungan Internasional \\ Fakultas Komunikasi dan Diplomasi Universitas Pertamina \\ Email: Kusumawardhana.up@gmail.com/ \\ indra.kusumawardhana@universitaspertamina.ac.id \\ Rusdi J. Abbas \\ Program Studi Hubungan Internasional \\ Fakultas Komunikasi dan Diplomasi Universitas Pertamina \\ Email: rusdiabbas@universitaspertamina.ac.id
}

Tulisan Diterima: 21-06-2018; Direvisi: 16-11-2018: Disetujui Diterbitkan: 16-11-2018

DOI: $\underline{\text { http://dx.doi.org/10.30641/ham.2018.9.153-174 }}$

\begin{abstract}
Post WTO's Joint Declarationon Trade and Economic Empowerment of Women in December 2017, at Buenos Aires, the involvement of Indonesia made it stand on the crossroads. Nonetheless, the polemic of gender equality and justice remains a task far from the end for Indonesia, especially if it refers to the fact that Indonesia has not yet completed the ratification of Law on gender equality and equity $(K K G)$. In fact, the substance of the Joint Declaration of Buenos Aires is the emphasis on gender equality and justice on economic activity, the absence of laws capable for regulating corporate behavior toward gender equality and justice in Indonesia will be a bad precedent in the future. In this context, this study probes the urgency of Law on Gender Equality and Equity $(K K G)$ in addressing Indonesia's involvement in the Joint Declaration of Buenos Aires. The core question, to tackle, why does Law on Gender Equality and Equity is important post Indonesia's involvement in WTO's Joint Declaration on Trade and Economic Empowerment? Utilizing some basic concepts such as globalization of economy, human rights, and gender perspective approach; as well as using qualitative methodologies in analyzing the problems. This article will conduct a socio-legal analysis of the urgency of the Gender Equality and Justice Act after Indonesia's involvement in the Buenos Aires Joint Declaration on Trade and Women's Economic Empowerment.
\end{abstract}

Keywords: Globalisation of Economy, Human Rights, Gender Equality and Equity, Indonesia, World Trade Organization

\begin{abstract}
ABSTRAK
Pasca Deklarasi Bersama Buenos Aires tentang Perdagangan dan Pemberdayaan Ekonomi Perempuan pada Desember 2017 silam, keterlibatan Indonesia kembali menjadikannya berada di persimpangan jalan. Jika merujuk pada kenyataan bahwa hingga kini Indonesia belum memiliki Undang - Undang Kesetaraan dan Keadilan Gender (UU-KKG), polemik kesetaraan dan keadilan gender tetap menjadi sebuah tugas yang jauh dari kata usai untuk Indonesia terutama dalam konteks penjaminan Hak Asasi Manusia. Padahal, substansi Deklarasi Bersama Buenos Aires adalah penekanan terhadap kesetaraan dan keadilan gender pada aktifitas
\end{abstract}


ekonomi. Dalam konteks tersebut, kajian ini dirajut dalam rangka mengangkat kembali urgensi UU-KKG, terutama dalam kaitan pemberdayaan ekonomi perempuan pasca Deklarasi Buenos Aires. Pertanyaan utama yang diajukan adalah mengapa UU-KKG penting bagi Indonesia pasca keterlibatannya di dalam Deklarasi Buenos Aires? Melalui pendekatan globalisasi ekonomi, hak asasi manusia, dan perspektif gender; serta menggunakan metodologi kualitatif dalam menganalisis permasalahan urgensi Undang-Undang Kesetaraan dan Keadilan Gender setelah Indonesia terlibat di dalam Deklarasi Bersama Buenos Aires tentang Perdagangan dan Pemberdayaan Ekonomi Perempuan.

Kata Kunci: Globalisasi Ekonomi, Hak Asasi Manusia, Kesetaraan dan Keadilan Gender, Indonesia, World Trade Organization

\section{PENDAHULUAN}

Pasca Indonesia turut serta di dalam kesepakatan World Trade Organization bertajuk Deklarasi Bersama Perdagangan dan Pemberdayaan Ekonomi Perempuan (Joint Declaration on Trade and Women's Economic Empowerment) di Buenos Aires pada Desember 2017. ${ }^{1}$ Kesetaraan dan Keadilan Gender, terutama terkait interelasi antara laki-laki-perempuan di dalam masyarakat Indonesia saat ini berada di persimpangan. Pada satu sisi, perjanjian tersebut ingin menguatkan relasi antara perempuan dengan pasar. Sedangkan pada sisi lainnya, kesetaraan dan keadilan gender di Indonesia masih belum memiliki Undang-Undang Kesetaraan dan Keadilan Gender yang dapat menguatkan pranata hukum Indonesia untuk mengatur isu terkait.

Dikarenakan persoalan kesetaraan dan keadilan gender telah menjadi sebuah isu yang sangat penting secara global. Dimana, setelah isu gender masuk sebagai salah satu tujuan utama transformasi langkah kolektif global yakni Sustainable Development Goals (SDGs) pada tahun 2015 lampau yang menjadi sebuah bukti nyata semakin kuatnya kepedulian masyarakat dunia terkait polemik kesetaraan dan keadilan gender (un.org). ${ }^{2}$ Kepedulian tersebut semakin mengemuka setelah pada Desember 2017 silam, World Trade Organization (WTO) berhasil mengonsolidasikan 118 negara untuk

1 Seperti yang telah dilansir di dalam situs resmi WTO. Dikutip secara daring di halaman https://www.wto.org/ english/news_e/news17_e/mc11_12dec17_e.htm, terakhir akses 20 Juni 2018

2 Pengakuan pentingnya kesetaraan dan keadilan gender sebagai sebuah kesepakatan tujuan kolektif dunia nampak dengan masuknya agenda tersebut dalam SDGs; Seperti yang telah dinyatakan melalui Sustainable Development Knowledge Platform di bagian Gender Equality and Women Empowerment. https://sustainabledevelopment.un.org/ topics/genderequalityandwomensempowerment, terakhir akses o1 November 2016. menandatangani Deklarasi Bersama. Deklarasi ini memuat agregasi komitmen negara-negara dunia untuk menjamin kesetaraan dan keadilan Gender pada sektor ekonomi dan perdagangan. Seperti yang dilansir oleh halaman resmi WTO "Seluruh anggota dan pengamat di dalam WTO telah secara spesifik menyetujui untuk menemukan cara terbaik mengatasi hambatan perdagangan, kurangnya akses ke pembiayaan perdagangan dan partisipasi perempuan yang tidak optimal di pasar pengadaan publik"3

Sedangkan, secara holistik jumlah penduduk perempuan di Indonesia 123.948.260 jiwa atau $49,02 \%$ dari penduduk Indonesia yang berjumlah 252,847.629 jiwa, berarti penduduk perempuan hampir mencakup setengah jumlah penduduk Indonesia. ${ }^{4}$ Adapun gambaran proporsi demografis terkait gender di Indonesia berdasarkan hasil Proyeksi Penduduk 2010-2035, pada 2015 rasio jenis kelamin penduduk Indonesia adalah sebesar 101, artinya dari seratus penduduk perempuan terdapat 101 penduduk laki-laki di Indonesia. Rasio jenis kelamin ini akan mencapai 100,17 pada 2035 , artinya jumlah penduduk laki-laki dan perempuan akan mencapai jumlah yang hampir sama. Namun ironisnya, tingkat Partisipasi Angkatan Kerja (TPAK) perempuan berdasarkan hasil tilikan Satuan Kerja Nasional (Sakernas) Agustus 2014 adalah sebesar 50,22 persen, terpaut sekitar 27 persen dengan TPAK laki-laki yang bernilai 83,05 persen. Angka TPAK ini menunjukkan bahwa dari 100 perempuan usia 15 tahun ke atas, hanya 50 orang yang tersedia untuk berpartisipasi di pasar kerja.

3 Seperti yang telah dilansir di dalam situs resmi WTO. Dikutip secara daring di halaman https://www.wto.org/ english/news_e/news17_e/mc11_12dec17_e.htm, terakhir akses 20 Juni 2018

4 Data Direktorat Jenderal Penduduk dan Catatan Sipil, 2013 Dapat diakses secara daring pada halaman Kemendagri. go.id.http://www.dukcapil.kemendagri.go.id/laporan. Terakhir akses o6 November 2016, Pada Pukul 20.0o WIB. 
Alasan utama yang menjadi permasalahan terjadinya ketimpangan keterlibatan perempuan pada pasar tenaga kerja adalah kuatnya sistem patriarki di dalam budaya Indonesia. Patriarki adalah tatanan kekeluargaan yang sangat mementingkan garis turunan bapak. ${ }^{5}$ Negara yang menganut sistem patriarki; cenderung membiarkan dominasi laki - laki terhadap perempuan bahkan perempuan selalu saja dipandang orang kedua setelah laki-laki di dalam dinamika bermasyarakat secara holistik maupun spesifik. Hal inilah yang membuat terjadinya pembagian kerja terhadap perempuan, karena laki-lakilah yang selalu mengambil keputusan, baik dalam keluarga, maupun di tempat kerja.

Adapun Silvia Walby mengatakan bahwa partiarkhi merupakan sistem terstruktur dan praktek sosial yang menempatkan kaum laki-laki sebagai pihak yang mendominasi, melakukan operasi dan mengeksploitasi kaum perempuan. Sistem ini ada dalam dua bentuk yakni (1) Private patriarchy (partiarkhi domestik) yakni yang menekankan kerja dalam rumah tangga sebagai steorotipe perempuan, dan; (2) Public patriarchy (patriarkhi publik) yakni yang memberikan stigmatisasi terhadap laki-laki sebagai pekerja di sektor publik yang sarat dengan karakter keras penuh tantangan. ${ }^{6}$ Sedangkan di Indonesia, kaum perempuan telah lama terjebak di dalam budaya patriarki dan diskriminasi tidak hanya pada tataran privat, namun juga telah secara struktural pada ranah publik. Seperti yang telah dijelaskan oleh Komisi Nasional perempuan Indonesia yang menyatakan bahwa berbagai perundang-undangan di Indonesia justru semakin mempertegas diskriminasi terhadap perempuan di masyarakat. Sehingga, dapat disimpulkan bahwa undangundang yang tersedia saat ini, belum mampu mengakomodasi secara komprehensif tentang perlindungan hak-hak perempuan dari bentukbentuk diskriminasi terhadap perempuan, dan pelanggaran hak asasi perempuan dalam pembangunan Indonesia. Walaupun upaya untuk mewujudkan Rancangan Undang-Undang tentang Kesetaraan dan Keadilan Gender (selanjutnya disebut RUU KKG) itu sendiri, sebenarnya telah memiliki dua landasan secara legal yang telah

5 Wulandari, Retno, Budaya Hukum Patriarki v. Feminis. Jurnal Hukum Dosen Tetap pada Fakultas Hukum Universitas Trisakti. 2010

6 Walby, Silvia, Theorizing Patriarchy Oxford Blackwell, USA. 1998, Hal.20 disepakati bersama terkait dengan persoalan Pengarusutamaan Gender (PUG) untuk kemajuan Indonesia, yang dijelaskan oleh Arivia yaitu (1) "Undang - undang Dasar Negara Kesatuan Republik Indonesia 1945 Pasal 31 Ayat 1: setiap warganegara baik perempuan maupun laki-laki mendapatkan kesempatan setara untuk mengecap pendidikan", (2) Inpres Nomor 9 tahun 2000 tentang Pengarusutamaan Gender dalam Pembangunan Nasional merupakan landasan hukum yang kuat untuk melaksanakan PUG khususnya bagi jajaran pemerintah. ${ }^{7}$

Pada titik ini, menguatnya desakan untuk mengatasi polemik ketimpangan yang dialami oleh perempuan pada sektor perdagangan dan ekonomi sebagai prakondisi penting keberlangsungan perekonomian dunia, setidaknya dapat dipahami melalui dua pendapat berikut; pertama, di tengah derasnya globalisasi ekonomi sekarang ini, Globalisasi telah menciptakan kesempatankesempatan yang sama bagi semua aktor dalam politik dan ekonomi global untuk satu sama lain mendapat keuntungan dari sistem tersebut. ${ }^{8}$ Sehingga problematika terkait diskriminasi antara perempuan dan laki-laki di dalam aktivitas perdagangan dan ekonomi secara general menemukan arti pentingnya. Pendapat kedua dinyatakan oleh Triyuni Soemartono pada aras nasional yang berpendapat bahwa pembatasan hak perempuan untuk mengekspresikan diri dan mengaktualisasikan dirinya sangat dipengaruhi oleh budaya patriarki yang telah sekian lama tertanam dalam pola pikir masyarakat Indonesia. Perempuan tereksklusi untuk mendapatkan haknya dalam masyarakat, rumah tangga, dan Negara. ${ }^{9}$

Menangkap dinamika tersebut, tulisan ini mencoba untuk menjawab mengapa UU- KKG sangat penting bagi Indonesia pasca keterlibatannya di dalam deklaras Buenos Aires? Pembahasan dalam artikel bertujuan untuk menjawab rumusan masalah dan pertanyaan penelitian dengan menggunakan kerangka pemikiran yang akan dirajut pada bagian setelah

7 Arivia, Gadis. Kebijakan Publik Dalam Pendidikan. Sebuah Kritik Dengan Perspektif Gender. Jurnal Perempuan No.23. 2002. h.83-94

8 Kusumawardhana, Indra. "GLOBALISATION AND STRATEGY: NEGARA, TERITORI DAN KEDAULATAN DI ERA GLOBALISASI.” Ilmu dan Budaya 40, no. 54 (2018).

9 Soemartono, Triyuni. Peran Pemerintah Dalam Pemberdayaan Perempuan. Yayasan Budi Arti, 2014. 
ini. Dengan demikian, analisis yang dilakukan akan menunjukkan bagaimana temuan-temuan itu diperoleh, serta bagaimana hasil penelitian telah melakukan identifikasi masalah, berikut juga kemungkinan pengembangannya. Dalam meretas pemahaman terkait interelasi antara Indonesia, Deklarasi Buenos Aires yang didorong oleh WTO, serta Kesetaraan dan Keadilan Gender di Indonesia. Setidaknya tiga hal tersebut memuat tiga konsep utama yang saling berkaitan yakni; Negara, Globalisasi Ekonomi dan Hak Asasi Manusia terkait Gender. Tiga konsep tersebut akan menjadi instrumen utama dalam menelaah masalah urgensi Undang-Undang Kesetaraan dan Keadilan Gender pasca Indonesia mengikuti Deklarasi Buenos Aires di tahun 2017.

Bertolak dari perkembangan globalisasi di abad ini, ternyata telah menarik banyak perhatian ilmuan secara lintas keilmuan. Spektrum isu utama yang menjadi area perdebatannya adalah seputar dampak globalisasi terhadap konsep Negara, teritori, dan kedaulatan (Wesphalian System).${ }^{10}$ Globalisasi yang memang mencakup beragam definisi telah menyentuh berbagai sendisendi kehidupan manusia hingga memunculkan fenomena meningkatnya interdependensi ekonomi, perubahan teknologi, homogenisasi kultural ataupun menguatnya peran institusiinstitusi global. ${ }^{11}$

Dalam tulisan ini, globalisasi dipahami sebagai “....serangkaian proses yang mendorong integrasi kegiatan ekonomi di pasar antara barang dan jasa, secara timbal-balik, di seluruh batas geografis, dan peningkatan arti dari rantai nilai lintas batas dalam arus ekonomi internasional"

(.... a set of processes leading to the integration of economic activity in factor, intermediate, and final goods and services markets across geographical boundaries, and the increased salience of crossborder value chains in international economic flows). ${ }^{12}$ Berlandaskan definisi tersebut dapat disimpulkan bahwa globalisasi berasal dari konsep ekonomi, berbeda dengan konsep internasionalisme pada era perang dingin yang

10 Kusumawardhana, Indra, Op.cit.

11 Benedek, Wolfgang, Koen De Feyter, and Fabrizio Marrella, eds. Economic Globalisation and Human Rights: EIUC Studies on Human Rights and Democratization. Cambridge University Press, 2007.

12 Prakash, A., Hart, J., 'Introduction' in Prakash, A., Hart, J. (eds.), Globalization and Governance (London: Routledge, 1999): 1-24. lebih berasal dari konsep politik. ${ }^{13}$ Dalam artian, proses interkonektivitas ekonomi dunia seturut kebutuhan aktor-aktor di pasar telah menciptakan sebuah sistem ekonomi yang mengaburkan batas-batas negara-bangsa sebagai suatu genus pengorganisasian politik yang awamnya dianggap muncul pasca perjanjian Westphalia di tahun $1648 .{ }^{14}$

Pertanyaan utama ketika berkaitan dengan globalisasi ekonomi adalah bagaimana implikasi konsep tersebut terhadap konsep negara-bangsa. Dimensi globalisasi ekonomi dapat dipahami sebagai keterbukaan ekonomi global dalam hal produksi, distribusi, manajemen, perdagangan dan keuangan yang meningkatkan akselerasi barang dan jasa, modal, ide, dan migrasi manusia. Setidaknya, menurut artikel ini, terdapat tiga posisi utama dalam meretas implikasi globalisasi ekonomi terhadap negara yakni; kelompok pertama menganggap negara akan mati dikarenakan semakin usang di dalam dinamika globalisasi ekonomi. Sedangkan kelompok kedua lebih berpijak pada argumentasi bahwasanya negara masih tetap bisa hidup dan berkembang, selama dapat mengembangkan instrumen kebijakan ekonomi yang mampu mengatasi tantangan globalisasi ekonomi. Kemudian kelompok ketiga menyatakan bahwasanya negara-negara akan melakukan refleksi kembali terkait eksistensi mereka di dalam pranata sosial dengan membuang beberapa fungsi politik dan ekonomi dalam rangka menghadirkan kebaruan dalam berbangsa dan bernegara. ${ }^{15}$

Posisi tulisan ini lebih condong kepada kelompok kedua, dimana dalam konteks

13 Kusumawardhana, Indra. "DARIINTERNASIONALISME KE GLOBALISASI: WHATNEXT?” Jurnal Populis 2, no. 3 (2017).

14 Indra Kusumawardhana (2017) di dalam artikelnya "Dari Internasionalisme ke Globalisasi: What Next" telah menjelaskan bahwasanya globalisasi muncul sebagai iI sebuah proses yang spontan dalam menghadapi perubahan yang begitu cepat, sementara internasionalisme didasarkan pada kesadaran mengambil segala tindakan yang terkait dengan kepentingan nasional maupun bersama. Sehingga ketika diambil sebuah platform sebagai contoh globalisasi dan internasionalisme. Platform globalisasi dalam hal ini adalah WTO dan IMF, sementara internasionalisme adalah PBB.

15 Lihat. Prakash, A., Hart, J., 'Introduction' in Prakash, A., Hart, J. (eds.), Globalization and Governance (London: Routledge, 1999): 1-24; atau Koen De Feyter di dalam Benedek, Wolfgang, Koen De Feyter, and Fabrizio Marrella, eds. Economic Globalisation and Human Rights: EIUC Studies on Human Rights and Democratization. Cambridge University Press, 2007. 
keikutsertaan Indonesia di deklarasi Buenos Aires, sangat penting untuk Indonesia melakukan upaya strategis dalam mengakomodasi tantangan globalisasi ekonomi yang dewasa ini semakin membalut dinamika kesetaraan dan keadilan gender di seluruh dunia. Oleh karena, globalisasi ekonomi telah mendapatkan momentum untuk merengkuh potensi melakukan agregasi preferensi kebijakan dalam konteks globalisasi politik, trajektori tersebut memuat kerawanan dapat melemahkan keberadaan negara yang terkadang acuh terhadap dinamika politik rendah (Low Politics) pada aras global. Dimana dua dekade lampau, David Held dan Anthony McGrew (1998) telah menyerukan bahwasanya globalisasi politik telah menciptakan Cosmopolitan Law dan Hukum Humaniter yang menjadi pemicu Negara semakin dilemahkan. ${ }^{16}$

Ketika mengaitkan fenomena tersebut dengan konsep Hak Asasi Manusia (HAM). Secara definisi, tulisan ini sepakat dengan pandangan Wolfgang Benedek yang menjelaskan bahwasanya inti dari HAM adalah aspirasi untuk melindungi harkat dan martabat seluruh manusia. ${ }^{17}$ Cara pandang yang meletakkan manusia sebagai perhatian utama ini pada akhirnya menekankan pada terbentuknya sistem universal yang menjadi kerangka bersama di dalam menjaga keberlangsungan hidup manusia di muka bumi ini.

Perihal ini didasarkan pada sistem nilai universal umum yang dikhususkan untuk menjaga kesucian hidup serta menyediakan kerangka kerja untuk membangun sistem hak asasi manusia yang dilindungi oleh norma dan standar yang diterima secara internasional. ${ }^{18}$

Pendapat ini berlandaskan pada definisi terkait HAM yang diejawantahkan di dalam artikel 1 dari Deklarasi Universal Hak Asasi Manusia (DUHAM) menjelaskan bahwasanya "Semua manusia dilahirkan bebas dan setara baik dalam martabat dan hak. Oleh karenanya, mereka .... harus memperlakukan satu sama lainnya dalam semangat persaudaraan." Berlandaskan adagium tersebut dapat disimpulkan bahwa pilar utama

16 Held, David. \& McGrew A. 1998, "The end of the old order?" Review ofInternational Studies, vol.24

17 Benedek, W. "Understanding human rights: manual on human rights education Antwerpen: Intersentia." NOTES 1 (2006), hal. 23.

18 Ibid, hal.28 dari sistem Hak Asasi Manusia, i.e. kebebasan, kesetaraan dan solidaritas.

Keterkaitan antara globalisasi ekonomi dengan HAM semakin mencuat ketika pada waktu perayaan 50 tahun UDHR; Economic, Social, and Cultural Rights (ECOSOC) selaku komite di bawah United Nations (UN) mengadopsi "Statement on Globalisation and Economic, Social and Cultural Rights". ${ }^{19}$ Pernyataan tersebut bersumber pada kekhawatiran ECOSOC terhadap kecenderungan negara-negara di dunia untuk terlibat di dalam gegap gempita globalisasi ekonomi, namun tanpa kecakapan dalam menggagas upaya meningkatkan kompatibilitas antara tren dan kebijakan ekonomi global dengan keberadaan aspek-aspek yang memuat hak-hak sosial, ekonomi dan kebudayaan. Hingga ECOSOC menyimpulkan bahwasanya,

"...globalisasi memuat risiko menurunkan sentralitas terhadap hak asasi manusia yang diutamakan oleh Piagam Perserikatan Bangsa-Bangsa dan dunia internasional pada umumnya".

Seperti yang telah ditekankan oleh pernyataan di atas, globalisasi ekonomi dengan HAM berkaitan secara erat pada aspek hak tenaga kerja di dalam aktivitas ekonomi. Sedangkan Organisasi Internasional yang diangkat oleh tulisan ini yakni WTO, selama ini menjadi sasaran kritik dari kelompok-kelompok anti-globalisasi dikarenakan sikap acuhnya terhadap proteksi HAM dalam konteks nasib tenaga kerja di seluruh dunia. Bahkan rekognisi WTO terhadap proteksi tenaga kerja semakin terungkap ketika pada waktu negosiasi DOHA, di bawah tekanan negara-negara berkembang, WTO menghapus agenda terkait hak-hak pekerja. ${ }^{20}$

Sehingga ketika WTO pada tahun 2017, WTO menggagas deklarasi bersama terkait "Trade and Women's Economic Empowerment". Merupakan sebuah langkah maju yang luar biasa dari organisasi yang telah lama dianggap

19 UN Committee on Economic, Social and Cultural Rights, 'Statement on Globalization and Economic, Social and Cultural Rights' (11 May 1998), direproduksi di dalamInternational Human Rights Reports, 6 (1999) 4:1176.

20 Ministerial Declaration, adopted on 14 November 2001 at Doha, WTO Doc. WT/MIN (o1)/DEC/1 of 20 November 2001. Lihat juga. Doha Work Programme - Decision Adopted by the General Council on 1 August2004, WTO Doc.WT/L/579 of 2 August2004, availableat http://www. wto.org/english/tratop_e/dda_e/ddadraft_3ijulo4_e.pdf (diakses: 20 Juni 2018). 
sebagai representasi kapitalisme global di bidang perdagangan lintas batas negara. Pada titik ini, perhatian WTO terhadap keberadaan perempuan sebagai salah satu upaya untuk lebih responsif terhadap permasalahan HAM menjadi diskursus yang menarik.

Jika inti dari HAM adalah kesetaraan dan keadilan, maka perempuan adalah gender yang telah lama berjuang untuk merengkuh kesetaraan dan keadilan hak-haknya sebagai manusia di dalam masyarakat. Sejak tahun 1970an, secara definisi gender dapat dipahami sebagai pelembagaan mendalam dari perbedaan seksual yang merasuki masyarakat kita. ${ }^{21}$ Sedangkan istilah gender berasal dari Middle English yaitu 'gendre', yang diambil dari era penaklukan Normandia pada zaman Prancis kuno. ${ }^{22}$ Lebih jauh lagi, Oakley di dalam buku "Sex, Gender, ond Society" mengartikan gender sebagai perbedaan jenis kelamin yang bukan biologis dan bukan kodrat Tuhan. Perbedaan biologis jenis kelamin merupakan kodrat Tuhan, karena secara permanen dan universal berbeda, sedangkan gender adalah behavioral differences (perbedaan perilaku) antara laki-laki dan perempuan yang socially constructed (dikonstruksikan secara sosial), yaitu perbedaan yang bukan kodrat atau bukan ciptaan Tuhan, melainkan diciptakan, baik oleh laki-laki maupun perempuan melalui proses sosial dan budaya yang panjang. ${ }^{23}$

Meskipun kondisi kesetaraan dan keadilan gender di dunia ini telah banyak berkembang, namun pada tataran yang partikular, struktur sosial masyarakat di berbagai belahan dunia ini masih menjadi halangan utama tercapainya kesetaraan dan keadilan gender. ${ }^{24}$ Salah satunya adalah struktur masyarakat patriarki. Patriarki adalah tatanan kekeluargaan yang sangat mementingkan garis turunan bapak. Secara etimologi, patriarki berkaitan dengan sistem sosial dimana ayah menguasai seluruh anggota keluarganya, harta miliknya, serta sumber-sumber ekonomi. Dimana proses terbentuknya sistem sosial yang patriakal

\footnotetext{
21 Okin, Susan Moller. "Justice and gender: An unfinished debate." Fordham L. Rev. 72 (2003): 1537.

22 Dikutip dari Naskah Akademis RUU KKG (Kesetaraan dan Keadilan Gender), Tim Kerja PUU-Deputi Perundangundangan DPR RI, 24 Agustus 2011, hlm. 11

23 Oakley, A. (1972). Sex, gender andsociety. London: Temple Smith.

24 Benedek, W, Op.cit. hal. 147.
}

tersebut diawali dari rumah sebagai tempat dimana sosialisasi awal dari konstruksi patriaki.

Perbedaan gender sebetulnya tidak menjadi masalah selama tidak melahirkan ketidakadilan gender. Namun ternyata perbedaan gender baik melalui mitos-mitos, sosialisasi, kultur, dan kebijakan pemerintah telah melahirkan uokum yang tidak adil bagi perempuan. Pada masyarakat patriarki, nilai-nilai kultur yang berkaitan dengan seksualitas perempuan mencerminkan ketidaksetaraan gender menempatkan perempuan pada posisi yang tidak setara. Karena nilai kultural adalah faktor mental yang menentukan perbuatan seseorang atau masyarakat pada lingkup yang lebih luas. ${ }^{25}$ Dalam cara hidup masyarakat Indonesia sendiri budaya patriarki masih sangat kental. Dalam kehidupan sosial, politik, ekonomi dan hukum nampak ketimpangan dan kondisi asimetris dan subordinatif terhadap perempuan tampak jelas. Dalam kondisi seperti ini proses marjinalisasi yang mengarah pada tindakan eksploitatif pun menjadi ancaman bagi pembangunan masyarakat Indonesia. Eksploitasi tersebut tidak hanya di tataran domestik (Rumah Tangga) namun sudah merasuk pada ranah publik.

\section{METODE PENELITIAN}

Penelitian ini merupakan penelitian deskriptif menggunakan pendekatan kualitatif. Metode kualitatif dianggap menjadi pilihan terbaik ketika mengkaji kehidupan manusia untuk kasus-kasus terbatas, sifatnya kasuistik dan kontekstual namun mendalam (in depth) dan bersifat total atau menyeluruh (holistic), dalam arti tidak mengedepankan pemilahan-pemilahan gejala secara konseptual ke dalam aspekaspeknya yang eksklusif dan terisolir. ${ }^{26}$ Siapa pun yang terlibat dalam bentuk penelitian ini harus menerapkan cara pandang penelitian yang bersifat induktif, berfokus terhadap makna individual dan menerjemahkan kompleksitas sebuah situasi. ${ }^{27}$

Teknik pengumpulan data menggunakan upaya mengumpulan data sekunder. Data sekunder diperoleh dari bahan hukum primer yang difokuskan kepada bahan-bahan studi

\footnotetext{
25 Koentjaraningrat. Kebudayaan, mentalitet, dan pembangunan: bungarampai. Gramedia, 1974.

26 Sutandyo Wignjosoebroto, "Hukum Konsep dan Metode", (Malang: Setara Press, 2013), hlm. 130

27 Bakry, Umar Suryadi. "Metode Penelitian Hubungan Internasional." (Yogyakarta: Pustaka Pelajar,2016).
} 
dokumen atau kepustakaan seperti buku, majalah, dokumen perjanjian internasional (Deklarasi Buenos Aires), makalah-makalah, jurnal, artikelartikel, surat kabar serta situs-situs internet yang berkaitan dengan objek yang ditulis. kepustakaan berupa, literatur terkait seperti naskah ilmiah, media massa, laporan penelitian serta dokumen yang relevan.

\section{PEMBAHASAN}

Bagian ini terbagi dalam dua sub-bab pembahasan yakni globalisasi ekonomi dan Indonesia dan Deklarasi Buenos Aires dalam kaitan kesetaraan dan keadilan gender di Indonesia. Bagian pertama fokus pada upaya menganalisis terkait implikasi globalisasi ekonomi terhadap Indonesia dalam konteks membangun pemahaman terkait posisi perempuan di dalam proses terkait. Sedangkan bagian kedua fokus pada menyandingkan deklarasi bersama Buenos Aires dengan kondisi kesetaraan dan keadilan gender di Indonesia hingga memunculkan urgensi untuk pembahasan UU-KKG dilanjutkan kembali.

\section{A. Globalisasi Ekonomi dan Indonesia: Posisi Perempuan Indonesia di Dalam Globalisasi Ekonomi}

Globalisasi ekonomi adalah suatu proses terintegrasinya ekonomi pada aras nasional ke dalam suatu sistem ekonomi pada aras global. Setidaknya, menurut Indra Kusumawardhana, ada tiga tantangan utama yang dimunculkan oleh globalisasi ekonomi terhadap konsep negara yakni semakin menguatnya peran Multinational Corporations, perdagangan finansial global, kemudian perdagangan bebas yang diterapkan oleh negara-negara dunia dalam kerangka perjanjian multilateral kawasan ataupun global. ${ }^{28}$ Seperti yang telah disinggung sebelumnya, keterkaitan paling erat antara globalisasi ekonomi dan Hak Asasi Manusia terletak pada proses ekstensifikasi pasar secara global ditunjang oleh keberadaan tenaga kerja sebagai daya dukung utamanya. Oleh karenanya, dari tiga aspek yang disebutkan tadi, analisis ini akan fokus pada dinamika pasar tenaga kerja perempuan Indonesia di dalam globalisasi ekonomi.

28 Kusumawardhana, Indra. "Globalisation And Strategy: “Negara, Teritori Dan Kedaulatan Di Era Globalisasi”." Ilmu dan Budaya 40, no. 54 (2018).
Ada dua proposisi yang saling berseberangan di dalam memahami keuntungan dan kerugian dari semakin terbukanya pasar dikarenakan perdagangan bebas. Berdasarkan beberapa penelitian yang dilakukan di beberapa negara; posisi pertama berpendapat bahwasanya keterbukaan perdagangan menyebabkan kemiskinan dan ketimpangan menurun, sedangkan posisi kedua mengkritik bahwasanya keterbukaan perdagangan menyebabkan kemiskinan dan ketimpangan pendapatan meningkat.

Ozcan dan $\mathrm{Kar}^{29}$, Okungbowa dan Eburajolo $^{30}$, dan Oyewale dan Amusat $^{31}$ setidaknya mewakili kelompok pertama yang percaya akan janji kesejahteraan yang digaungkan oleh globalisasi. Tetapi nuansa optimis yang digawangi oleh kelompok pro-globalisasi ekonomi ditantang oleh kelompok yang pesimis terhadap janji-janji globalisasi ekonomi. Chen dan Ravallion $^{32}$, Abbot $^{33}$, dan Twyford $^{34}$ merupakan beberapa cendekia yang menantang argumentasi dari kelompok pro-globalisasi ekonomi. Mereka sepakat bahwasanya globalisasi ekonomi alihalih membawa kesejahteraan justru semakin mempertajam disparitas antara mereka yang masuk dalam kategori the have dan the have not. Globalisasi dapat menjadi sumber masalah terkait ketimpangan pendapat manakala proses produksi mengalami diversifikasi dan beberapa bagian ditransfer ke luar negeri. ${ }^{35}$

29 Ozcan, G., Kar, M. (2016). Does foreign tradeliberalization reduce poverty in Turkey? Journal ofEconomic and Social Development, 3(1): 157-173.

30 Okungbowa, F.O.E., dan Eburajolo, O.C. (2014). Globalization and poverty rate in Nigeria: An empirical analysis. International Journal of Humanities and Social Science, 4(11): 126-135.

31 Oyewale, I.O., dan Amusat, W.A. (2013). Impact of globalization on poverty reduction in Nigeria. Interdisciplinary Journal of Contemporary Research in Business, 4(11).

32 Chen, S., and M, Ravallion. (2007). Absolute poverty measures for the developing world, 1981- 2004, World Bank Policy Research Working Paper No. 4211.

33 Abbott, K.W. Development policy in the new millennium and the Doha 'DevelopmentRound'. Asian Development Bank, (2003).

34 Twyford, P. (2003). Does trade liberalisation exacerbate or reduce poverty? Trade and globalization in the lead up to the Cancun Ministerial. Address to Council for International Development (CID) Trade Forum. Oxfam International. Landon.

35 Feenstra, R.C., dan G.H. Hanson. (1999). The impact of outsourcing and high-technology capital on wages: Estimates for the U.S., 1979-1990, Quarterly Journal of Economics, 114(3). 
Grafik 1

Ekspor, Impor dan Tingkat Kemiskinan

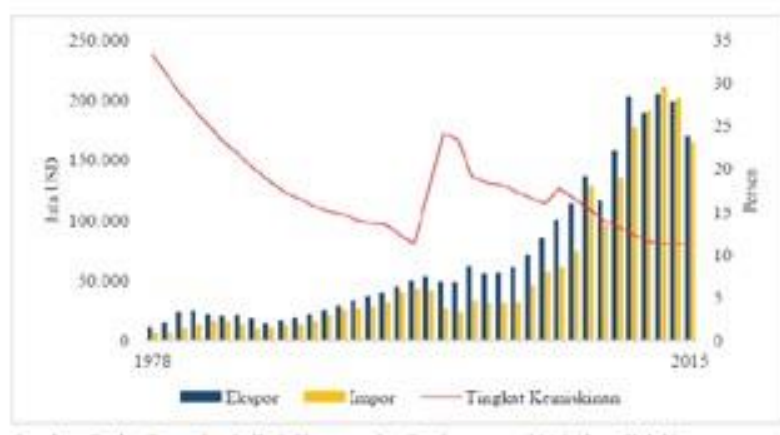

Sumbler Badan Pusat Statistilk \& Kenserterian Pendagnagan, 2016 (dara diolab)

Sumber: Agusalim, Lestari \& Fanny S. Pohan. "Globalisasi Ekonomi Dan Pengaruhnya Terhadap Kemiskinan Dan Ketimpangan Pendapatan Di Indonesia" Modus \& Ristek Dikti (2017).

Pada titik ini, cara pandang posisi kedua lebih merepresentasikan kondisi Indonesia saat ini. Di tengah kontestasi perdebatan antara kelompok pro dan kontra terhadap globalisasi ekonomi. Indonesia secara aktif terintegrasi di dalam sirkuit globalisasi ekonomi dunia yang sangat kompetitif. Komitmen Indonesia dapat ditakar dari begitu banyaknya perjanjian internasional yang diratifikasi oleh Indonesia sebagai negara yang berdaulat. Imbas dari langkah progresif ini, secara makro, terbukanya pasar Indonesia selama tiga puluh tahun ke-belakang telah meningkatkan neraca perdagangan internasional Indonesia, serta menurunkan angka kemiskinan (Grafik.1). Namun meningkatnya neraca perdagangan Indonesia sepertinya tidak terlalu memengaruhi angka ketimpangan pendapatan di dalam negeri (Grafik.2).

\section{Grafik 2}

Ekspor, Impor dan Tingkat Ketimpangan

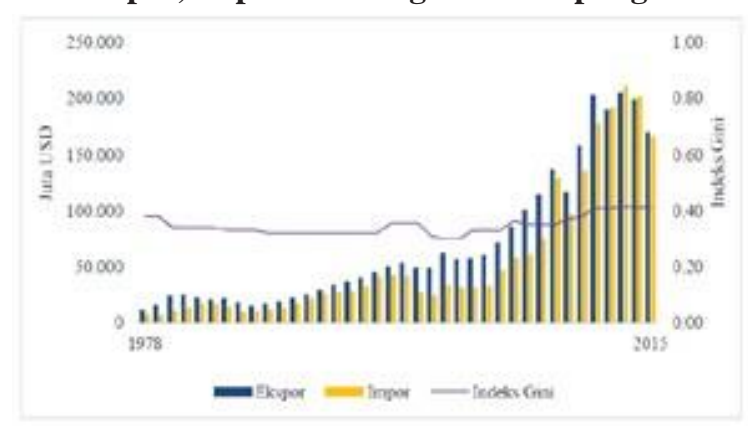

Sumber: Agusalim, Lestari \& Fanny S. Pohan. "Globalisasi Ekonomi Dan Pengaruhnya Terhadap Kemiskinan Dan Ketimpangan Pendapatan Di Indonesia" Modus \& Ristek Dikti (2017).
Dengan demikian, kondisi-kondisi kontradiktif antara meningkatnya keterkaitan Indonesia dengan globalisasi ekonomi melalui perjanjian perdagangan bebas ternyata tidak membawa angka ketimpangan pendapatan di Indonesia pada tataran yang signifikan, bahkan cenderung stagnan. Lebih problematis lagi ketika melihat posisi perempuan di dalam angkatan kerja Indonesia ternyata ada di angka yang mengkhawatirkan. Sudah tentu, hal ini harus menjadi perhatian pemerintah dalam merumuskan trajektori kebijakan perdagangan kedepannya. Dikarenakan ketimpangan yang nampak dari kondisi tingkat pendapatan dan kesetaraan di dalam angkatan kerja merupakan pemahaman penting di dalam merawat kesetaraan dan keadilan gender di Indonesia.

Sedangkan, pasca Indonesia menjadi bagian deklarasi bersama WTO pada Desember 2017. ${ }^{36}$ Tantangan ini semakin nyata dikarenakan konsolidasi kebijakan global menuntut Indonesia melakukan rekonfigurasi kebijakan terutama dalam kaitan mengadopsi kesepahaman di dalam deklarasi tersebut. Salah satu poin penting yang sangat krusial dalam diskursus ini adalah terkait tujuan utama dari deklarasi tersebut ingin menghilangkan batasan-batasan terkait women's economic empowerment. Walaupun deklarasi bersama tersebut telah mengundang kritik keras jaringan komunitas peduli kesetaraan dan keadilan gender dunia yang menganggap deklarasi tersebut bukanlah sebuah solusi yang tepat dalam menyeleseikan masalah ketimpangan gender di dunia. Alih-alih demikian, deklarasi tersebut justru dituduh merupakan upaya WTO mengalihkan perhatian dunia terhadap kegagalannya dalam mengakomodasi aspek kesetaraan dan keadilan gender yang merupakan salah satu bagian dari dimensi penting di dalam diskursus Hak Asasi Manusia. Seperti yang termuat di dalam pendapat berikut.

"Organisasi hak-hak perempuan dari seluruh dunia telah menolak deklarasi ini hanya sebagai "pink herring" yang dirancang untuk mengalihkan perhatian dari bahaya yang dilakukan WTO. Jika ada minat yang tulus pada pemerintah terhadap hak asasi manusia, terutama perempuan, sudah barang tentu akan ada perubahan peraturan

36 Seperti yang telah dilansir di dalam situs resmi WTO Dikutip secara daring di halaman https://www.wto.org/ english/news_e/news17_e/mc11_12dec17_e.htm, terakhir akses 20 Juni 2018 
perdagangan internasional yang saat ini menurunkan upah perempuan, memindahkan perempuan dari tanah mereka, memprivatisasi barang publik untuk memperkaya perusahaan multinasional. Kami muak dengan kesetaraan gender yang digunakan sebagai taktik sinis untuk membenarkan neoliberalisme.". ${ }^{37}$

Oleh karenanya, Indonesia harus memahami bahwasanya deklarasi Buenos Aires memuat berbagai sudut pandang, dimana salah satunya adalah keraguan masyarakat sipil global terkait ketulusan dari niat deklarasi tersebut terhadap pencapaian kesetaraan dan keadilan gender di dunia ini. Namun pemahaman tersebut harus dimulai dari menelaah terlebih dahulu terkait deklarasi yang telah dinyatakan dengan kondisi kesetaraan dan keadilan gender di Indonesia. Dari sana, sudah saatnya Indonesia memiliki definisi dan rumusan kebijakan sendiri dalam menyikapi deklarasi WTO tersebut melalui memunculkan UU-KKG yang memang sejak awal dibahas di parlemen Indonesia diperuntukkan sebagai payung hukum di dalam pemberdayaan perempuan di Indonesia.

\section{B. Deklarasi Buenos Aires Dalam Kaitan Kesetaraan dan Keadilan Gender di Indonesia}

Sub-Bab ini akan fokus membedah konten Deklarasi Buenos Aires serta mengkaitkannya dengan kondisi kesetaraan dan keadilan gender di Indonesia ketika dikaitkan dengan substansi yang ada di dalam dokumen resmi deklarasi bersama tersebut. Joint Declaration on Trade and Women's Economic Empowerment disepakati pada tanggal 12 Desember 2017. Dengan tujuan utama to remove barriers to, and foster, women's economic empowerment. ${ }^{38} 118$ anggota dan observer di Organisasi Internasional WTO terlibat di dalam deklarasi tersebut. Alasan utama mengapa WTO sebagai Organisasi Internasional yang telah sekian lama menjadi sasaran kritik berbagai organisasi non-pemerintah dunia terkait keabaiannya terhadap nasib buruh serta kesetaraan dan keadilan gender di dalam

37 Apwld.org, n.d. http://apwld.org/press-release-164womens-rights-groups-call- on-governments-toreject-the-wto-declaration- on-womens-economicempowerment/

38 Seperti yang telah dilansir di dalam situs resmi WTO. Dikutip secara daring di halaman https://www.wto.org/ english/news_e/news17_e/mc11_12dec17_e.htm, terakhir akses 20 Juni 2018 globalisasi ekonomi adalah niat WTO untuk turut berkontribusi di dalam agenda UN yakni Global Development Goals yang memang memberikan perhatian terhadap kesetaraan dan keadilan gender. ${ }^{39}$ Seperti yang dilansir di dalam situs resmi WTO sebagai berikut "Tindakan ini juga akan berkontribusi pada Tujuan Pembangunan Global PBB, termasuk Tujuan Pembangunan Berkelanjutan untuk mencapai kesetaraan gender melalui pemberdayaan perempuan dewasa dan anak-anak (SDG 5)". ${ }^{40}$

Berdasarkan adopted text (Terjemahan bebas) yang telah dipublikasi oleh WTO, dasardasar pengakuan dari munculnya deklarasi bersama tersebut memuat 6 pokok pemikiran yakni:

1. Mengakui pentingnya memasukkan perspektif gender ke dalam upaya mendorong pertumbuhan ekonomi inklusif, dan menguatkan peranan kunci yang dapat dimainkan oleh kebijakan yang responsif gender dalam mencapai pembangunan sosioekonomi yang berkelanjutan;

2. Mengakui bahwa kebijakan perdagangan inklusif dapat berkontribusi untuk memajukan kesetaraan gender dan pemberdayaan ekonomi perempuan, yang memiliki dampak positif pada pertumbuhan ekonomi dan membantu mengurangi kemiskinan;

3. Mengakui bahwa perdagangan dan investasi internasional adalah mesin pertumbuhan ekonomi untuk negara-negara berkembang dan maju, dan bahwa meningkatkan akses perempuan ke peluang dan menghilangkan hambatan untuk partisipasi mereka dalam ekonomi nasional dan internasional berkontribusi terhadap pembangunan ekonomi berkelanjutan;

4. Mengakui kebutuhan untuk mengembangkan intervensi berbasis bukti yang mengatasi berbagai hambatan yang membatasi peluang bagi perempuan dalam perekonomian;

5. Menguatkan 5 Tujuan Pembangunan Berkelanjutan dalam Agenda 2030 PBB untuk Pembangunan Berkelanjutan, yang 
bertujuan untuk mencapai kesetaraan gender dan memberdayakan semua perempuan dan anak perempuan;

6. Menegaskan kembali komitmen kami untuk secara efektif melaksanakan kewajiban berdasarkan Konvensi tentang Penghapusan Segala Bentuk Diskriminasi Terhadap Perempuan, yang diadopsi oleh Majelis Umum PBB pada 18 Desember 1979.

Berlandaskan dasar-dasar pemikiran tersebut, negara-negara yang terlibat di dalam Deklarasi Buenos Aires sepakat untuk melakukan kolaborasi dalam bentuk:

1. Saling Berbagi pengalaman masing-masing terkait dengan kebijakan dan program untuk mendorong partisipasi perempuan dalam ekonomi nasional dan internasional melalui pertukaran informasi Organisasi Perdagangan Dunia (WTO), sebagaimana layaknya, dan pelaporan sukarela selama proses peninjauan kebijakan perdagangan WTO;

2. Berbagi praktik terbaik untuk melakukan analisis kebijakan perdagangan berbasis gender dan untuk memantau dampaknya;

3. Membagi metode dan prosedur untuk pengumpulan data-data terkait gender, penggunaan indikator, metodologi pemantauan dan evaluasi, serta analisis statistik yang berfokus pada gender terkait dengan perdagangan;

4. Bekerja bersama-sama melalui WTO untuk menghilangkan hambatan bagi pemberdayaan ekonomi perempuan dan meningkatkan partisipasi mereka dalam perdagangan; dan

5. Memastikan ketersediaan alat-alat pendukung Aid for Trade dan pengetahuan untuk menganalisis, merancang, dan menerapkan kebijakan perdagangan yang lebih responsif gender.

Seluruh substansi dan wacana kolaborasi dari Deklarasi Buenos Aires menekankan pada upaya aktif pemerintahan negara untuk menjamin keterlibatan perempuan di dalam proses

pembangunan ekonomi yang diharapkan mampu mendorong pertumbuhan ekonomi dunia. Seperti yang juga dijelaskan olehWTO sendiri bahwasanya meskipun perempuan merepresentasikan setengah dari populasi dunia, mereka hanya berkontribusi sebesar 37\% dari gross domestic product (GDP) dunia dan awamnya hanya menjalankan usaha kecil menengah. Bahkan di beberapa negara berkembang, bisnis yang dimiliki perempuan hanya mampu menyumbang 3-6\% dari GDP negara. Survei dari International Trade Centre di 20 negara-negara berkembang mengungkap bahwa dari 5 perusahaan eksportir hanya satu yang dimiliki oleh perempuan. Di 155 negara dunia, setidaknya ada satu instrumen hukum yang menjadi penghalang untuk perempuan memenuhi hak dan kesempatannya di bidang ekonomi. Bahkan prediksi yang tersedia membutuhkan 170 tahun untuk mencapai kesetaraan gender di dunia ini. $^{41}$

Kondisi ini juga terjadi di Indonesia, Ketimpangan yang nampak dalam sistem sosial yang ada di Indonesia tidak hanya terkait rasa aman dari ancaman bersifat kekerasan mental maupun fisik semata dan keterlibatan dalam proses politik dalam menentukan arah komunitas maupun negara. Pada aspek yang berkelindan langsung dengan pembangunan ekonomi Indonesia juga nampak ketimpangan dan ketidakadilan yang sangat tajam. Pada aspek ekonomi terdapat enam artikel yang mengejawantahkan corak ekonomi Indonesia yang bernafaskan demokrasi yakni Pasal 27(2), 28A, 28D (2), 28H (2);(3);(4), Pasal 33 dan Pasal 34 (1) dan (2) dari Undang-Undang Dasar Negara Republik Indonesia.

Meskipun, dengan ditetapkannya UndangUndang Nomor 39 Tahun 1999 tentang Hak Asasi Manusia, Indonesia sebagai negara yang berdaulat juga merespon dinamika yang terjadi di aras global setelah meratifikasi kesepakatan dunia terkait kesetaraan dan keadilan gender baik United Nations under Convention on the elimination of Discrimination Against Woman (CEDAW) maupun Millenium Development Goals (MDGs). Namun sudahkah kesetaraan dan keadilan gender dihadirkan secara maksimal dalam mewujudkan kesetaraan dan keadilan gender? Sejauh mana hak-hak perempuan diperoleh setelah reformasi yang mengedepankan penerapan demokrasi di negara Indonesia?

\footnotetext{
$41 \quad$ Ibid
} 
Di Indonesia, konsep kesetaraan dan keadilan gender yang merujuk pada upaya untuk menghilangkan diskriminasi terhadap perempuan baru muncul pada Garis Besar Halauan Negara (GBHN) tahun 1993-1998 (Ditetapkan oleh MPR) yang menyatakan perempuan memiliki hak- hak dan kewajiban- kewajiban yang sama dengan lakilaki. Meskipun Majelis Permusyawarahan Rakyat (MPR) pada waktu itu belum merujuk secara eksplisit pada upaya untuk kesetaraan dan keadilan gender namun hak-hak dan kewajiban-kewajiban yang sama antara laki-laki dan perempuan dapat diartikan telah berupaya mengarah pada konsep kesetaraan dan keadilan gender. ${ }^{42}$

Hal ini semakin diperkuat dengan memunculkan konsep kesetaraan gender di dalam Garis Besar Halauan Negara (GBHN) 1999-2004 yang diimplementasikan dengan mengeluarkan Instruksi Presiden No. 9/2000 tentang Pengarusutamaan Gender (PUG) dalam pembangunan; Berlandaskan pada GBHN tersebut, yang merupakan kehendak politik bangsa Indonesia yang strategis, sebagaimana GBHN periode sebelumnya, bahwa kedudukan perempuan perlu ditingkatkan dengan memperhatikan kodrat, harkat dan martabat perempuan. Komitmen pemerintah, sebagaimana Undang-Undang Nomor 7 tahun 1984 tentang Pengesahan Konvensi Mengenai Penghapusan segala bentuk diskriminasi terhadap perempuan, bahwa segala warga negara bersamaan kedudukannya di dalam hukum dan pemerintahan, sehingga segala bentuk diskriminasi terhadap perempuan harus dihapuskan karena tidak sesuai dengan pancasila dan Undang-Undang Dasar tahun 1945. ${ }^{43}$

Sayangnya sejak pemerintah menetapkan Undang-Undang No. 10 tahun 2004 mengenai Pembentukan Peraturan Perundang-undangan; MPR sebagai lembaga tertinggi negara tidak dimasukkan dalam hierarki undang-undang dan regulasi di Indonesia. Sehingga konsep terkait hak-hak perempuan akhirnya terletak pada Undang-Undang Dasar Negara Kesatuan Republik Indonesia pasal 28D (3) yang menyatakan bahwa Setiap warga negara berhak memperoleh kesempatan yang sama dalam pemerintahan. Serta Pasal 28H (2) yang berbunyi Setiap orang

\footnotetext{
42 Al Uyun, Dhia. 2014. Women's Right in Indonesian Constitution, International Journal of Humanities and Social Science, Vol.4, No.8(1); June 2014

43 Soemartono, Triyuni. Peran Pemerintah Dalam
} Pemberdayaan Perempuan. Yayasan Budi Arti, 2014. mendapat kemudahan dan perlakuan khusus untuk memperoleh kesempatan dan manfaat yang sama guna mencapai persamaan dan keadilan. Dua butir dalam Undang-Undang Dasar tersebut memberikan penekanan pada dua konsep yakni kesetaraan dan keadilan.

Memang pasca reformasi serta demokratisasi Indonesia pada tahun 1999, Hak Asasi Manusia menjadi wacana sangat penting dalam pembangunan Indonesia. Kebebasankebebasan yang ditawarkan pada era demokrasi juga memberikan ruang untuk diskursus terkait kesetaraan gender berkembang baik pada tataran akademis maupun praksis dalam bernegara dan berbangsa. Namun pasca demokratisasi, setiap warga negara tidak hanya menikmati hak dan kebebasannya, tetapi juga memikul tanggung jawab bersama dengan warga negara lainnya untuk kepentingan bersama di masa depan. Namun menurut Budi Winarno, ada banyak problematika yang harus diseleseikan oleh Indonesia jika ingin meningkatkan kualitas kehidupan berbangsa dan bernegara di Indonesia. Salah satunya adalah masalah pemberdayaan perempuan, dengan tujuan agar perempuan mendapatkan ruang artikulasi publik yang memadai, kultur patriarki dalam masyarakat harus diubah. Marginalisasi kaum perempuan diakibatkan oleh struktur sosial yang tidak adil dan bias gender. ${ }^{44}$

Selaras dengan 2 (dua) pendapat tersebut Triyuni Soemartono menyatakan bahwasanya perlu ditingkatkan komitmen dan kepekaannya terhadap realita, bahwa jumlah penduduk perempuan beda sedikit dari jumlah kaum laki-laki yaitu $50 \%$ an dari jumlah penduduk Indonesia, yang perlu ditingkatkan potensi, kemampuan dan pendidikannya, supaya tidak menjadi beban lingkungannya dengan tidak melupakan kodrati seorang perempuan, apalagi kalau sudah berkeluarga, bahwa seorang ibu adalah pendidik utama dan pertama, isteri seorang suami, ibu dari anak-anaknya, bisa membantu suami sebagai pencari nafkah dan seorang anggota masyarakat. 
Tabel. $1^{45}$

Beberapa Undang -Undang Terkait Gender di Indonesia

\begin{tabular}{|c|c|c|}
\hline Law of Regularixe & Date & Coatrat \\
\hline Indropuin Coestintiber & 1945 & Censtitution \\
\hline Mampet Lax & 1974 & Mamuge sahs and namiage age \\
\hline Laboed Lax (Law No.132003) & 20003 & Matemal lexte, nenitrual levie \\
\hline 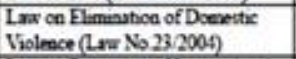 & 2004 & $\begin{array}{l}\text { Definisce of doewerse violesse, protectioe } \\
\text { of viction, punithmest }\end{array}$ \\
\hline 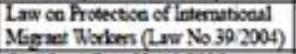 & 2004 & 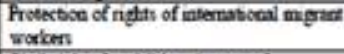 \\
\hline CrialLow (Lw No.12/2006) & 2006 & 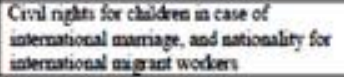 \\
\hline
\end{tabular}

Namun, dari 11 Undang - Undang yang ditetapkan oleh Dewan Perwakilan Rakyat (DPR) bersama dengan Presiden berkaitan dengan hakhak perempuan dalam kerangka mengakomodasi urgensi kesetaraan dan keadilan gender; hanya enam dari keseluruhannya yang memiliki manfaat praktis terhadap perempuan. Di antara Peraturan Perundang-undangan yang mengandung muatan perlindungan hak asasi perempuan adalah: Undang-Undang Nomor 39 Tahun 1999 tentang HAM, Undang-Undang Nomor 23 Tahun 2004 tentang Penghapusan KDRT, Undang-Undang Nomor 12 Tahun 2006 tentang Kewarganegaraan, Undang-Undang Nomor 21 Tahun 2007 tentang Pemberantasan Tindak Pidana Perdagangan Orang, dan Undang-undang Politik (UU No. 2 Tahun 2008 dan UU No. 42 Tahun 2008). Kemudian Kepres No. 181 Tahun 1998 tentang Pembentukan Komisi Nasional Anti Kekerasan terhadap Perempuan atau Komnas Perempuan yang diubah dengan Perpres Nomor 65 Tahun $2005 .{ }^{46}$ Serta Undang-Undang Republik Indonesia Nomer 8 Tahun 2012 terkait Pemilihan Anggota Dewan Perwakilan Rakyat, Dewan Perwakilan Rakyat Daerah serta Dewan Perwakilan Daerah yang memperkuat keterwakilan perempuan di parlemen.

Sedangkan peraturan yang menjadi dasar untuk memperkuat peran perempuan dalam pembangunan Indonesia ada pada Inpres Nomor 9 Tahun 2000 tentang Pengarustamaan Gender (PUG). Inpres ini menjadi dasar adanya upaya berperspektif gender bagi seluruh kebijakan dan program pembangunan nasional, tanpa kecuali. Baik kebijakan di pusat maupun di daerah

45 Country Gender Profile: Indonesia, Final Report, Japan International Cooperation Agency. 2011. Hal.11.

46 Kania, Dede. “ Hak Asasi Perempuan dalam Peraturan Perundang-Undangan di Indonesia. Jurnal Konstitusi, Volume 12 Nomor 4. 2015. haruslah berperspektif gender, apabila tidak maka kebijakan tersebut harus diganti.

Sedangkan, sekali lagi jika fokus pada salah satu indikator PUG yakni Rasio Kesempatan Kerja Terhadap Penduduk Usia Kerja di Indonesia. Masih ada disparitas yang jauh antara kesempatan kerja untuk perempuan dibandingkan kesempatan kerja untuk laki -laki. Pada tahun 2011 rasio kesempatan kerja untuk laki-laki ada pada persentase 78.32 sedangkan perempuan hanya $45.34 \%$. Di tahun 2014, angka tersebut tidak banyak berubah yakni $78.27 \%$ untuk lakilaki sedangkan untuk perempuan adalah 47.08. Perlu diperhatikan bahwa rasio kesempatan kerja merupakan gambaran kesetaraan dan keadilan terkait akses setiap individu (laki-laki dan perempuan) di Indonesia dalam berkontribusi dalam dinamika pembangunan Indonesia secara menyeluruh. Disparitas yang cukup jauh tersebut diperkuat lagi dengan Tingkat Kesenjangan Upah Gender di Indonesia yang terus meningkat dari tahun ke tahun.

\section{Gambar 1}

Tingkat Kesenjangan Upah Gender Indonesia 2011-2014

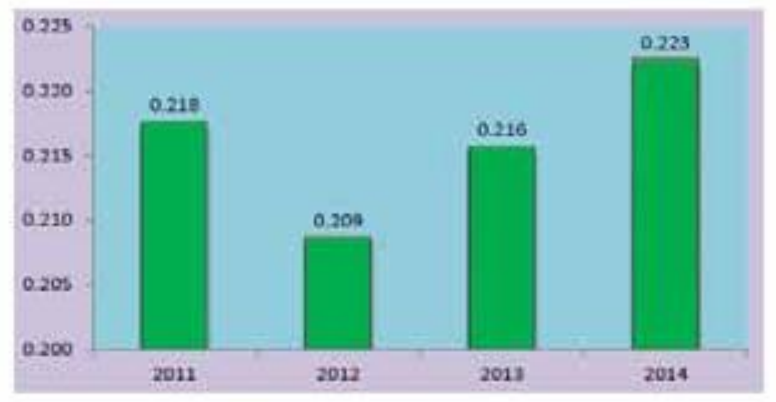

Sumber te5, Dioiah dan Sakernas Aqustus 2011-2014

Angka rata - rata dari perempuan yang aktif secara ekonomi menunjukan bahwa dalam rentang hampir satu dekade perempuan yang menjadi bagian dari aktifitas ekonomi di Indonesia yang juga menjadi bagian dari agregasi Gross Domestic Product (GDP) Indonesia tidak pernah mampu menembus prosentase $40 \%$. Angka pada tahun 2002 menunjukan 37.17\% sedangkan di tahun 2011 bulan Februari adalah 39.48\%. Masih sangat timpang antara perempuan yang memiliki kesadaran ataupun memiliki kemampuan untuk turut berkontribusi dalam arus pembangunan Indonesia. 
Dalam konteks rendahnya akses perempuan dalam pasar tenaga kerja serta ketimpangan dan ketidakadilan dalam perlakuan terhadap perempuan di bidang ekonomi. Global Gender Gap 2014 melaporkan bahwa meskipun tingkat unemployment rate untuk perempuan telah menurun dari $9 \%$ menjadi $6,8 \%$ pada tahun 2012, namun angka tersebut masih jauh lebih tinggi dari laki - laki (5,8\%). Sedangkan Asian Development Bank (ADB) terkait Indonesia menyatakan bahwa "Limited access to training, gender segregation in the labor market, as well as family responsibilities and childcare, are the key factors that limit women's engagement in the labor market". ${ }^{47}$ Merujuk pendapat tersebut dapat disimpulkan bahwa pemberdayaan terhadap wanita yang lemah membuat wanita memiliki keterbatasan dalam memilih partisipasinya dalam arus pembangunan Indonesia.

Tabel. 2

Data Pendapatan Perempuan di Beberapa Negara

\begin{tabular}{|c|c|c|c|}
\hline Country & $\begin{array}{l}\text { Earned income } \\
\text { Female (US,S) }\end{array}$ & $\begin{array}{l}\text { Earned incoms } \\
\text { Male (US,\$) }\end{array}$ & $\begin{array}{l}\text { Ratio of women's } \\
\text { eamings to men's } \\
\text { earnings (K) }\end{array}$ \\
\hline Phillppinas & 3.213 & 5.409 & 59 \\
\hline Sti Lanka & 2579 & 5.009 & 51 \\
\hline Indonesia & 2.289 & 4,434 & 52 \\
\hline india & 1.569 & 4,130 & 38 \\
\hline Singapcre & 16,459 & 32,089 & 51 \\
\hline
\end{tabular}

Merujuk data numerik dari proyeksi penduduk menurut kelompok umur dan jenis kelamin. Di tahun 2016 jumlah penduduk laki laki adalah 129,988,7 dan akan meningkat pada angka 134. 657, 7 di tahun 2019, sedangkan pada rentang waktu yang sama pada tahun 2015 jumlah penduduk Indonesia berjenis kelamin perempuan adalah 128.716,3 dengan peningkatan pada angka 133.416, 9 di tahun 2019. Sedangkan jika menimbang bahwa data Badan Statistik Nasional (BPS) Indonesia mengungkap bahwa jumlah Rumah Tangga di Indonesia telah ada pada angka

64.771,60. Dua kondisi tersebut menunjukan bahwasanya proporsi jumlah penduduk menurut jenis kelamin dengan jumlah Rumah Tangga yang begitu besar tentunya memiliki dimensi tuntutan ekonomi yang harus dipenuhi oleh kesempatan

47 Hoque, Uzma S. "Summary of Indonesia’s GenderAnalysis." (2015). kerja yang proporsional dalam lingkup nasional, sedangkan di tengah resesi ekonomi dunia sekarang ini unemployment rate Indonesia telah berada pada angka 6.2\% di tahun 2015 (Indonesia masih jauh di bawah Malaysia di angka 3\% dan Singapura di angka 2\% $\left.{ }^{48}\right){ }^{49}$ Jalan ke depan menuntut rekonfigurasi pendekatan legal yang lebih kuat untuk Indonesia agar dapat mengonsolidasikan kekuatan yang menggerakan roda pembangunan bangsa ini. Terutama harmonisasi atau sinergitas antar gender yang hingga saat ini masih sangat terpaku dalam jeruji sistem sosial patriakal.

Sebenarnya, upaya untuk memberdayakan perempuan dalam pembangunan telah dilakukan melalui berbagai pendekatan pembangunan yang ditujukan untuk meningkatkan peran perempuan dalam pembangunan. Pembangunan adalah suatu perubahan perilaku (kognisi, efeksi, dan keterampilan) positif yang akan membawa kemanfaatan bagi orang banyak yaitu, masyarakat secara keseluruhan. Jangan sampai Indonesia abai dalam memperhatikan sejarah, Pembangunan atau Development dahulu telah menjadi sebuah retorika yang sangat kuat pada era rezim orde baru dengan jargon Trilogi Pembangunan: Stabilitas Nasional yang dinamis, Pertumbuhan ekonomi Tinggi dan Pemerataan pembangunan dan hasilhasilnya. Dimana model Pembangunan tersebut turut memiliki andil semakin tajamnya disparitas terkait kesetaraan dan keadilan gender di Indonesia melalui berbagai segregasi peran antara laki-laki dan perempuan dengan adanya berbagai organisasi seperti Pembinaan Kesejahteraan Keluarga (PKK) dan Dharma Wanita. ${ }^{50}$ Ternyata ketika pada akhirnya mengalami kerontokan sistem moneter dikarenakan tekanan-tekanan baik eksternal maupun domestik hingga akhirnya mewujud dalam krisis multidimensi di tahun 1998, seketika pada waktu krisis tersebut, perempuan menjadi pihak yang paling menjadi korban dari runtuhnya perekonomian Indonesia.

Pertumbuhan ekonomi Indonesia yang

48 BPS, n.d. https://www.bps.go.id/linkTabelStatis/view/ id/983. Terakhir akses o6 November 2016, Pada Pukul 20.00 WIB.

49 Indonesia Economic Outlook, n.d. http://www.focuseconomics.com/countries/indonesia. Terakhir akses 20 Juni 2018, Pada Pukul 20.0o WIB.

50 Siahaan, Asima Yanti. 2002. "Decentralisation in Indonesia Bringing Governance toWomen." Paper Presented at DevNet Conference, Massey University, NewZealand. 
mendapatkan pujian setinggi langit oleh Bank Dunia (World Bank) sebagai salah satu Asian Economic Miracle. ${ }^{51}$ Ternyata pada tahun 1997 mulai mengalami masalah dikarenakan ketergantungan terhadap utang luar negeri, kegagalan manajemen ekonomi makro, korupsi dan kesalahan dalam mengimplementasikan kebijakan-kebijakan dari International Monetary Fund (IMF) yang akhirnya malah menghancurkan perekonomian Indonesia hingga berujung pada terjadinya krisis ekonomi-politik. Ternyata krisis tersebut memiliki dampak yang luar biasa terhadap merosotnya kualitas hidup perempuan di Indonesia. Disparitas gender yang sudah mulai semakin dipersempit dengan adanya kebijakan wajib belajar 9 (sembilan) tahun, dan hampir sudah dapat dieliminasi di tahun 1997; kembali melebar pasca krisis yang terjadi. ${ }^{52}$

Laporan UNDP menyatakan bahwa angka perempuan yang memiliki penghasilan di bawah garis kemiskinan berlipat ganda dari $11 \%$ menjadi $22 \%$ di Indonesia pada tahun 1998, upah untuk perempuan merosot menjadi sepertiga dari upah laki-laki. Oleh karena itu, perempuan terpaksa untuk menerima jam kerja yang lebih lama untuk dapat memenuhi kebutuhan rumah tangga. ${ }^{53}$ Dapat dikatakan perempuan di Indonesia pada waktu itu menjadi pihak yang mendapat respon penurunan kualitas hidup yang paling keras. Hal tersebut tidak terlepas dari dikotomi perempuan sebagai sosok ibu yang memiliki tugas utama yakni “women's primary role as mothers is to look after her family, a group, a class, a company or the state, without demanding power or prestige in return". ${ }^{4}$ Dimana Suryakusuma menyebut bahwa cara orde baru membenamkan ideologi "stateibuism" adalah dengan mengartikulasikan definisi perempuan sebagai 'appendages and companions to their husbands, as procreators of the nation, as mothers and educators of children, as housekeepers, and as members of

\footnotetext{
51 Hadi, Syamsul, Dominikus Dolet, Jerry S. Manuel, and S. B. Khrisna. Strategi pembangunan Mahathir dan Soeharto: politik industrialisasi dan modal Jepang di Malaysia dan Indonesia. Pelangi Cendekia, 2005.

52 Country Gender Profile: Indonesia, Final Report, Japan

International Cooperation Agency. 2011. Terakhir akses o6 November 2016, Pada Pukul 20.00 WIB.

53 UNDP, 2016. http://hdr.undp.org/en/composite/GDI. Terakhir akses o6 November 2016, Pada Pukul 20.0o WIB.

54 Nieuwenhuis, D. "Ibuism and Priyayization: Path to Power?" di dalam buku editan Elsbeth Locher- Scholten and Anke Niehof (eds) Indonesian Women inFocus Foris Publications: Holland-USA. 1987.
}

Indonesian society'. ${ }^{55}$ Bertolak dari pengalaman tersebut, sangat penting untuk memperhatikan realitas sejarah yang terjadi terkait keadilan dan kesetaraan gender di Indonesia. Untuk itu memahami pemberdayaan perempuan harus memperhatikan sensitivitas yang dalam agar tidak dilakukan secara asal dan dangkal sehingga malah semakin mempertajam ketimpangan di antara perempuan dan laki-laki sebagai anggota masyarakat. Oleh karena itu, Undang - Undang Kesetaraan dan Keadilan Gender menjadi sangat penting jika ingin mempercepat pencapaian persamaan substantif serta kesempatan yang sama antara perempuan dan laki-laki dalam menikmati hak-hak sipil, politik, ekonomi, sosial, dan budaya.

Salah satu aspek yang harus diperhatikan adalah kapasitas perempuan dalam bersaing untuk dapat bekerja di berbagai bidang secara maksimal. Studi dari Julie H. Gallaway dan Alexander Bernasek terhadap angkatan kerja Indonesia mengungkap data empiris yang dianalisis melalui jumlah sampel penelitian 8.654 pekerja laki-laki dan perempuan. Kajian tersebut menunjukan bahwa lebih dari $70 \%$ pekerja yang diteliti bekerja di tiga kategori besar yakni: sektor agrikultur (41\%), sektor penjualan (18\%) dan sektor produksi-konstruksi (12\%). Sedangkan dari kategori tersebut ketika melihat distribusi serta komposisi berdasarkan gender maka nampak data bahwa perempuan kebanyakan berkarya di empat tempat yakni sektor agrikultur (1.404), penjualan (912), proses produksi (411), dan jasa (272). Dimana keempat sektor tersebut tidak terlalu membutuhkan literasi bahkan pendidikan yang tinggi. Sedangkan di sektor profesional yang membutuhkan literasi dan pendidikan tinggi hanya 36 perempuan yang berkarya di profesi tersebut. ${ }^{56}$

Data tersebut memberikan gambaran bahwa pemberdayaan masih sangat memiliki potensi untuk ditingkatkan demi tercapainya kesetaraan dan keadilan gender. Namun ketiadaan UndangUndang Kesetaraan dan Keadilan Gender membuat upaya meningkatkan kontribusi

\footnotetext{
55 SURYAKUSUMA, Julia. 1996. The State and Sexuality in The New Order Indonesia in Sears, Laurie J.ed. Fantasizing the Feminism in Indonesia Duke University Press: Durham\& London.

56 Gallaway, Julie H., and Alexandra Bernasek. "Gender and informal sector employment in Indonesia." Journal of Economic Issues 36, no. 2 (2002): 313-321.
} 
perempuan dalam pembangunan kurang kuat. Selama ini strategi pengarusutamaan gender berlandaskan pada Inpres Nomor 9 Tahun 2000 meliputi: (1) Perencanaan, termasuk di dalamnya perencanaan yang responsif gender/gender budgeting; (2) Pelaksanaan; dan (3) Pemantauan dan Evaluasi. Sedangkan pada tataran yang lebih rendah, dasar hukum pelaksanaan PUG diatur dalam Keputuran Menteri Dalam Negeri Nomor 15 Tahun 2008 tentang Pedoman Umum Pelaksanaan Pengarusutamaan Gender dalam Pembangunan di daerah yang kemudian dilakukan pembahuruan dengan terbitnya Peraturan Menteri Dalam Negeri Nomor 67 Tahun 2011.

\section{Dikarenakan implementasi PUG membutuhkan dukungan anggaran yang responsif gender. Melalui Peraturan Kementerian Keuangan Nomor 119 Tahun 2009 tentang Petunjuk Penyusunan Penelaahan Rencana Kerja dan Anggaran Kementerian Negara/Lembaga dan Penyusunan, Penelaahan, Pengesahan, dan Pelaksanaan Daftar Isian Pelaksanaan}

Anggaran Tahun Anggaran 2010; tindak lanjut dari seluruh instrumen peraturan tersebut adalah sebanyak 7 (tujuh) Kementerian didorong untuk menerapkan Anggaran Responsif Gender (ARG) ke dalam program dan kegiatan masing-masing Kementerian, yaitu: Kementerian Keuangan, Kementerian Pertanian, Kementerian Pendidikan Nasional, Kementerian Kesehatan, Kementerian Pekerjaan Umum, Kementerian Pemberdayaan Perempuan dan Perlindungan Anak; dan Badan Perencanaan Pembangunan Nasional. Serta untuk mempercepat pelaksanaan PUG, juga telah diterbitkan Surat Edaran mengenai Strategi Nasional Percepatan Pengarusutamaan Gender melalui Perencanaan dan Penganggaran yang Responsif Gender. ${ }^{57}$

Pada kenyataaannya sudah berbagai macam perundang-undangan dikeluarkan pemerintah sebagai payung hukum untuk menjamin berjalannya konsep kesetaraan dan keadilan gender; tidak hanya di tataran nasional namun diharapkan mampu menderas hingga dilaksanakan di daerah. Tetapi permasalahan/kendala yang dihadapi masih menghadang perkembangan pergerakan perempuan untuk pembangunan yang responsive gender. Dalam konteks permasalahan

57 Susiana, Sali. "URGENSI UNDANG-UNDANG TENTANG KESETARAAN DAN KEADILAN GENDER.” Kajian 19.3 (2016): 219-234. tersebut Triyuni Soemartono dalam bukunya "Peran Pemerintah Dalam Pemberdayaan Perempuan" telah memberikan elaborasi permasalahan yang dihadapi dalam pelaksanaan pengarusutamaan gender dalam pembangunan adalah sebagai berikut: (1) masih rendahnya kualitas hidup dan peran perempuan, yang antara lain, disebabkan oleh terjadinya kesenjangan gender dalam hal akses, manfaat, dan partisipasi dalam pembangunan, serta penguasaan terhadap sumber daya, terutama di bidang politik, jabatanjabatan publik, dan di bidang ekonomi, baik antar-provinsi maupun antarkabupaten/ kota; serta rendahnya kesiapan perempuan dalam mengantisipasi dampak perubahan iklim, krisis energi, krisis ekonomi, bencana alam dan konflik sosial, serta terjadinya penyakit. (2) masih rendahnya perlindungan terhadap perempuan dari tindak kekerasan, yang ditandai dengan maraknya kasus-kasus kekerasan terhadap perempuan yang belum diiringi dengan peningkatan kuantitas dan kualitas layanan terhadap para korban tindak kekerasan, masih terdapat ketidaksesuaian antarproduk hukum yang dihasilkan, termasuk antara produk hukum yang dikeluarkan oleh pemerintah pusat dengan daerah berkaitan dengan perlindungan terhadap perempuan. (3) masih lemahnya kelembagaan pengarusutamaan gender di Indonesia. Angka GDI (Gender-related Development Index) mengukur pencapaian dari dimensi dan indikator yang sama dengan HDI (Human Development Index), namun dengan memperhitungkan kesenjangan pencapaian antara perempuan dan laki-laki. GDI adalah HDI yang disesuaikan oleh adanya kesenjangan gender, sehingga selisih yang semakin kecil antara GDI dan HDI menyatakan semakin kecilnya kesenjangan gender.

Berdasarkan Indonesia Human Development Report 2014, angka HDI 0,684 dan angka GDI 0.927. Ketimpangan antara angka HDI dibandingkan dengan angka GDI menunjukkan, bahwa keberhasilan pembangunan sumber daya manusia secara keseluruhan belum sepenuhnya diikuti dengan keberhasilan pembangunan gender, atau masih terdapat kesenjangan gender. Ukuran lain dalam pembangunan pemberdayaan perempuan adalah Gender Empowerment Measurement (GEM), Angka GEM Indonesia pada tahun 2005 adalah 0,40 kemudian pada tahun 2013 menjadi 0,52. Angka tersebut adalah 
terendah dari ASEAN-5 (Indonesia, Malaysia, Filipina, Singapura dan Thailand). GEM di Indonesia berkembang jauh di bawah HDI Indonesia dari tahun ke tahun. Dengan begitu menunjukan bahwa kesetaraan dan keadilan gender dalam aspek ekonomi dan politik berjalan sangat lambat.

Oleh karena itu jika saja Draft RUU KKG yang diajukan hasil Panja 9 Desember 2013 dilanjutkan pembahasannya hingga paripurna; maka kesetaraan dan keadilan gender akan semakin kuat adanya di Indonesia. Sebagai contoh dalam RUU tersebut pada pasal 7 terdapat aturan yang berbunyi sebagai berikut:

Tindakan KKG di bidang ketenagakerjaan sebagaimana dimaksud dalam Pasal 4 huruf $\mathrm{c}$ dilaksanakan melalui:

a. Pemberian akses, kesempatan, dan perlakuan yang sama:

1. untuk memilih dan menentukan pekerjaan di semua bidang; dan

2. dalam penerimaan, penempatan, pendidikan dan pelatihan kerja, serta promosi jabatan di semua jenjang;

b. Pemberian upah, tunjangan, dan jaminan sosial yang sama, serta penyediaan fasilitas lainnya; dan

c. Jaminan dan perlindungan atas kesehatan dan keselamatan kerja, termasuk kesehatan reproduksi dan perlindungan dari tindak kekerasan seksual. $"{ } 58$

Pasal tersebut akan semakin mempertajam sensitivitas Indonesia ketika harus berkelindan dengan konsep gender, dengan adanya pasal yang mengatur kesetaraan dan keadilan gender dalam bernegara dan berbangsa maka pemberdayaan perempuan akan semakin diperkuat. Terutama ketika dalam pasal 4 RUU-KKG juga disebutkan bahwa Kesetaraan dan Keadilan Gender dapat diperjuangkan melalui pembentukan dan pengembangan studi mengenai Gender di setiap perguruan tinggi. Dengan melakukan diseminasi wacana terkait gender secara ekstensif dan intensif secara intelektual maka dapat mendorong

58 Naskah RUU KKG (Kesetaraan dan Keadilan Gender), hlm. 4. Dapat di lihat secara daring di halaman http://www. koalisiperempuan.or.id/wp-content/uploads/2014/o4/ DRAF-RUU-KKG-Panja-9-desember-2013-ke-Baleg.pdf. Terakhir akses 20 Juni 2018. pemahaman yang lebih baik ketika berbicara tentang gender.

Selain itu tindak lanjut dari diseminasi tersebut dapat digunakan sebagai landasan untuk merumuskan strategi pemberdayaan perempuan yang lebih tepat dalam mendukung pembangunan Indonesia, tentu saja dari diseminasi itu juga dapat ditemukan titik temu antara konsep kesetaraan dan keadilan gender dengan berbagai nilai - nilai agama ataupun lokal yang dianut oleh masyarakat Indonesia secara luas. Selain itu pemahaman akan konsep kesetaraan dan keadilan gender masih sangat terbatas di semua kalangan, demikian pula pemahaman akan pentingnya anak sebagai generasi penerus bangsa masih harus ditingkatkan. Keterbatasan pemahaman itu juga terjadi di antara para perencana dan pelaksana pembangunan, yang selanjutnya turut memperlambat upayaupaya pengintegrasian konsep tersebut ke dalam berbagai kebijakan, program, dan kegiatan pembangunan. Instruksi presiden No. 9 tahun 2000 mengenai keharusan semua sektor pembangunan untuk melaksanakan Pengarusutamaan Gender (PUG), merupakan tonggak penting dalam sejarah terhadap segala usaha untuk mencapai kesetaraan gender yang merupakan bagian dari Hak Asasi Manusia dan Keadilan Sosial. Namun karena program pembangunan pemberdayaan perempuan dan peningkatan kesejahteraan dan perlindungan anak dapat dilaksanakan dengan baik, apabila ada Undang-Undang yang menjadi payung hukum untuk pelaksanaannya di berbagai tataran secara komprehensif serta kelembagaan yang kuat dalam menangani upaya tersebut, baik di aras nasional maupun daerah.

Undang - Undang mengenai Kesetaraan dan Keadilan Gender (UU KKG) sama sekali tidak bermaksud untuk memberikan keistimewaan kepada perempuan dan mendiskriminasikan pihak laki-laki. Keberadaan Undang-Undang tersebut justru memiliki utilitas untuk memperkuat peraturan perundang-undangan yang telah ada yang mengatur hak dan kewajiban yang setara bagi setiap warga negara (dari sudut pandang lakilaki dan perempuan) dan juga secara implisit membantu peraturan perundang-undangan agar tidak bias gender. Karena sifatnya memperkuat, maka materi muatan yang ada dalam UU KKG nantinya sama sekali tidak mengganti materi muatan yang ada dalam peraturan perundangundangan lama. Jadi, jika UU-KKG ini 
diberlakukan, berbagai penguatan atau afirmasi perempuan dalam undang-undang yang sudah ada tidak perlu dicabut terlebih dahulu. UU ini justru akan memperkuat berbagai penguatan atau afirmasi perempuan yang sudah ada di berbagai undang-undang tersebut sehingga antara peraturan yang sudah ada dengan RUU KKG menjadi harmonis.

Sebenarnya RUU KKG telah menjadi salah satu Rancangan Undang-Undang (RUU) yang masuk dalam daftar Program Legislasi Nasional (Prolegnas) Tahun 2014. Namun hingga akhir masa bakti DPR RI periode 2009-2014, RUU ini tidak berhasil dirampungkan pembahasannya, penyebab mengenai tidak usainya pembahasan tersebut salah satunya adalah perbedaan persepsi terkait konsep "gender" di benak berbagai pihak yang terlibat dalam pembahasan tersebut. Dalam rapat Paripurna terakhir DPR RI periode 20092014 RUU ini dikembalikan kepada komisi VIII. ${ }^{59}$ Sedangkan pembahasan RUU KKG telah berlangsung dalam waktu relatif lama dan telah melibatkan banyak stake holder terkait. Adapun secara urgensi; Undang-Undang untuk mengakomodasi kesetaraan dan keadilan gender memiliki muatan strategis untuk bangsa ini. Karena ketika berbicara ketimpangan sosial sebagai ekses dari globalisasi, banyak argumentasi yang menganggap bahwa wanita sangat rentan menjadi objek eksploitasi oleh kekuatan pasar. Seperti yang diungkap oleh Monique Deveaux bahwa:

Globalisasi telah mempertajam kemiskinan perempuan di banyak bagian dunia, dan pada tataran tertentu mengurangi kendali mereka atas jenis dan kondisi kerja, dan atas keadaan kehidupan keluarga dan tempat tinggal mereka. Ketika kekuatan kapital transnasional telah tumbuh, kekuatan warga negara individu untuk membuat keputusan tentang aspek-aspek penting dari kehidupan sehari-hari telah menyusut; pekerja perempuan sering kali paling mudah dieksploitasi, sering bekerja di bawah kondisi informal dan ilegal (misalnya pekerja tekstil dan garmen di utara dan selatan). ${ }^{60}$

59 Susiana, Sali. "URGENSI UNDANG-UNDANG TENTANG KESETARAAN DAN KEADILAN GENDER.” Kajian 19.3 (2016): 219-234.

60 Shiva, Vandana. "Food rights, free trade, and fascism." Di dalam Globalizing Rights: The Oxford Amnesty Lectures (1999), ed. Matthew Gibney (Oxford: Oxford University Press), hal 107.
Selaras dengan pendapat tersebut, pemenuhan HAM Perempuan adalah penghormatan, pemenuhan dan perlindungan yang membutuhkan intervensi positif dan langkah tindak pro-aktif berupa legislasi, peraturan per undang-undangan, rancangan (design) kebijakan, alokasi sumber daya, dan program untuk mewujudkan hak-hak tersebut. Intervensi positif dan langkah-langkah pro aktif perwujudan penuh hak asasi manusia termasuk hak asasi perempuan menghendaki bahwa Negara (Eksekutif, Legislatif, Yudikatif dan seluruh masyarakat) mengemban tiga tingkat tanggung jawab: penghormatan, pemenuhan dan perlindungan hak, termasuk penegakannya. Masing-masing tingkat saling terkait, tidak dapat dipisah-pisahkan satu sama lain. Oleh karena itu Seandainya RUU KKG yang diajukan hasil Panja 9 Desember 2013 dilanjutkan pembahasannya hingga paripurna; maka kesetaraan dan keadilan gender akan semakin kuat adanya di Indonesia.

\section{KESIMPULAN}

Kajian ini telah melakukan berbagai tilikan mendalam terkait implikasi keterlibatan Indonesia di dalam Deklarasi Buenos Aires yang digawangi oleh WTO dengan polemik kesetaraan dan keadilan gender di Indonesia. Pertanyaan utama artikel ini yakni mengapa Undang-Undang Kesetaraan dan Keadilan Gender penting bagi Indonesia pasca keterlibatannya di Deklarasi Bersama Buenos Aires telah dijawab dengan pokok argumentasi; pertama, intensifikasi globalisasi ekonomi yang juga melanda Indonesia akan semakin memberikan desakan bagi Indonesia untuk mampu meresponsnya dengan sebuah kebijakan yang secara aktif dapat mengakomodasi konsep kesetaraan dan keadilan gender sebagai bagian dari Hak Asasi Manusia. Kedua, kondisi kesetaraan dan keadilan gender di Indonesia jika mengacu pada kesepakatan di dalam Deklarasi Buenos Aires masih jauh dari kondisi yang ideal. Ketiga, ketiadaan UU-KKG menjadikan Indonesia belum memiliki sebuah payung hukum yang komprehensif dalam mengembangkan kebijakan responsif gender terutama dalam kaitan women's empowerment yang menjadi substansi utama di dalam deklarasi Buenos Aires.Oleh karenanya, UU-KKG menjadi suatu jawaban yang paling konkret seandainya Indonesia memang secara 
tulus ingin mencapai suatu kondisi kesetaraan dan keadilan gender di dalam sistem sosialekonominya. Adicita tersebut sangat penting terutama dalam koridor terjaminnya kesetaraan antara laki-laki dan perempuan di dalam aktivitas ekonomi sebagai bentuk perhatian Indonesia pada aspek non-discriminatory yang menjadi salah satu inti dari Hak Asasi Manusia

\section{SARAN}

Pasca Deklarasi Buenos Aires, dapat diperhatikan bahwa trajektori agenda global tidak hanya menyangkut aspek politik dan sosial, namun telah menyentuh dimensi ekonomi yang memang menjadi platform utama dari globalisasi. Setelah SDGs memasukkan isu gender di dalam agenda ke-lima, sekarang WTO juga memainkan perannya untuk mengkonsolidasikan kebijakan negara-negara dunia terkait women's empowerment. Pada titik ini, Undang-Undang tentang KKG diperlukan untuk mempercepat tercapainya persamaan substantif dan kesempatan yang sama antara laki-laki dan perempuan dalam menikmati hak-hak sipil, politik, ekonomi, sosial, dan budaya. Selain itu, UU tentang KKG diperlukan sebagai payung hukum guna mencapai akses dan kondisi yang setara antara laki-laki dan perempuan. 


\section{DAFTAR PUSTAKA}

\section{Buku dan Artikel Jurnal}

Abbott, K.W. Development policy in the new millennium and the Doha 'Development Round'. Asian Development Bank, (2003).

Arivia, Gadis. Kebijakan Publik Dalam Pendidikan. Sebuah Kritik Dengan Perspektif Gender. Jurnal Perempuan No.23. 2002. h.83-94

Badan Pusat Statistik, 2011. Laporan Studi Kualitatif Partisipasi Perempuan Dalam Politik.

Bakry, Umar Suryadi. "Metode Penelitian Hubungan Internasional." (Yogyakarta: Pustaka Pelajar, 2016).

Bemmelan, Sita Van. Isu Gender di Bidang Pendidikan. Semiloka Pengarusutamaan Gender Bagi Para Perencana di Lingkungan Pendidikan Nasional Kabupaten Badung dan Kota Denpasar. 2002. h.9.

Bemmelen, Sita, and Mies Grijns. "Competing Gender Identities after Reformasi?" ANTROPOLOGI INDONESIA 30.1 (2006).

BENEDEK, W. "Understanding human rights: manual on human rights education Antwerpen: Intersentia." NOTES 1 (2006):147.

Benedek, Wolfgang, Koen De Feyter, and Fabrizio Marrella, eds. Economic Globalisation and Human Rights: EIUC Studies on Human Rights and Democratization. Cambridge University Press, 2007.

Chen, S., and M, Ravallion. (2007). Absolute poverty measures for the developing world, 1981- 2004, World Bank Policy Research Working Paper No. 4211.

Correia, Maria C., and Ian Bannon. "Gender and its discontents: Moving to men-streaming development." The other half of gender: Men's issues in development (2006): 245260.
Deveaux, Monique. Gender and justice in multicultural liberal states. Oxford University Press, 2007.

De Beauvoir, Simone. The second sex. Random House, 2014.

Feenstra, R.C., dan G.H. Hanson. (1999). The impact of outsourcing and high-technology capital on wages: Estimates for the U.S., 1979-1990, Quarterly Journal of Economics, 114(3).

Gallaway, Julie H., and Alexandra Bernasek. "Gender and informal sector employment in Indonesia." Journal of Economic Issues 36, no. 2 (2002): 313-321

Held, David. \& McGrew A. 1998, "The end of the old order?" Review of International Studies, vol.24.

Hoque, Uzma S. "Summary of Indonesia's Gender Analysis.” (2015).

Koentjaraningrat. Kebudayaan, mentalitet, dan pembangunan: bungarampai. Gramedia, 1974.

Kusumawardhana, Indra. "DARI INTERNASIONALISME KE GLOBALISASI: WHAT NEXT?" Jurnal Populis 2, no. 3 (2017).

Kusumawardhana, Indra. "GLOBALISATION AND STRATEGY: NEGARA, TERITORI DAN KEDAULATAN DI ERA GLOBALISASI." Ilmu dan Budaya 40, no. 54 (2018).

Naskah Akademis RUU KKG (Kesetaraan dan Keadilan Gender), Tim Kerja PUU-Deputi Perundang-undangan DPR RI, 24 Agustus 2011, hlm. 11

Nieuwenhuis,

Djajadiningrat. "Ibuism and Priyayization: Path to Power?"di dalam buku editan Elsbeth Locher- Scholten and Anke Niehof (eds) Indonesian Women in Focus Foris Publications: Holland-USA. 1987.

Oakley, Anne. "Sex, gender andsociety." London: Temple Smith (1972). 
Okin, Susan Moller. "Justice and gender: An unfinished debate." Fordham L. Rev. 72 (2003): 1537.

Okungbowa, F.O.E., dan Eburajolo, O.C. (2014). Globalization and poverty rate in Nigeria: An empirical analysis. International Journal of Humanities and Social Science, 4(11): 126-135.

Oyewale, I.O., dan Amusat, W.A. (2013). Impact of globalization on poverty reduction in Nigeria. Interdisciplinary Journal of Contemporary Research in Business, 4(11).

Ozcan, G., Kar, M. (2016). Does foreign trade liberalization reduce poverty in Turkey? Journal of Economic and Social Development, 3(1): 157-173.

Prakash, A., Hart, J., 'Introduction' in Prakash, A., Hart, J. (eds.), Globalization and Governance (London: Routledge, 1999): 1-24

Siahaan, Asima Yanti. 2002. "Decentralisation in Indonesia: Bringing Governance toWomen." Paper Presented at DevNet Conference, Massey University, NewZealand.

Shiva, Vandana. "Food rights, free trade, and fascism." Di dalam Globalizing Rights: The Oxford Amnesty Lectures (1999), ed. Matthew Gibney (Oxford: Oxford University Press), hal 87-108.

Suryakusuma, Julia. 1996. The State and Sexuality in The New Order Indonesia in Sears, Laurie J. ed. Fantasizing the Feminism in Indonesia Duke University Press: Durham\& London.

Susiana, Sali. "URGENSI UNDANG-UNDANG TENTANG KESETARAAN DAN KEADILAN GENDER.” Kajian 19.3 (2016): 219-234.

Sutandyo Wignjosoebroto, "Hukum Konsep dan Metode", (Malang: Setara Press, 2013), hlm. 130

Soemartono, Triyuni. Peran Pemerintah Dalam Pemberdayaan Perempuan. Yayasan Budi Arti, 2014.

Hadi, Syamsul, Dominikus Dolet, Jerry S. Manuel, and S. B. Khrisna. Strategi pembangunan Mahathir dan Soeharto: politik industrialisasi dan modal Jepang di
Malaysia dan Indonesia. Pelangi Cendekia, 2005.

Retno, Wulandari. 2010.Budaya Hukum Patriarki v. Feminis. Jurnal Hukum Dosen Tetap pada Fakultas Hukum Universitas Trisakti.

Twyford, P. (2003). Does trade liberalisation exacerbate or reduce poverty? Trade and globalization in the lead up to the Cancun Ministerial. Address to Council for International Development (CID) Trade Forum. Oxfam International. Landon.

\section{Sumber Online:}

Apwld.org, n.d. http://apwld.org/press-release164 -womens-rights-groups-call-ongovernments-to-reject-the-wto-declarationon-womens-economic-empowerment/

Doha Work Programme - Decision Adopted by the General Council on 1 August 2004, WTO Doc.WT/L/579 of 2 August 2004, available at http://www.wto.org/english/tratop_e/ dda_e/ddadraft_31jul04_e.pdf (diakses: 20 Juni 2018).

Kemendagri.go.id. http://www.dukcapil. kemendagri.go.id/laporan. Terakhir akses 06 November 2016, Pada Pukul 20.00 WIB.

Koalisiperempuan.or.id, 2013. http://www. koalisiperempuan.or.id/wp-content/ uploads/2014/04/DRAF-RUU-KKG-Panja9-desember-2013-ke-Baleg.pdf.Terakhir akses 06 Juni 2016, Pada Pukul 20.00 WIB.

UN, n.d. http://www.un-documents.net/a37r63. htm. Terakhir akses 06 November 2016, Pada Pukul 20.00 WIB.

Country Gender Profile: Indonesia, Final Report, Japan International Cooperation Agency. 2011. Terakhir akses 06 November 2016, Pada Pukul 20.00 WIB.

UN.org, 2016. https://sustainabledevelopment. un.org/about._Terakhir akses 06 November 2016, Pada Pukul 20.00 WIB.

UNDP, n.d. http://hdr.undp.org/en/composite/ GDI. Terakhir akses 06 November 2016, Pada Pukul 20.00 WIB.

BPS, n.d. https://www.bps.go.id/website/pdf_ publikasi/watermark\%20_Laporan\%20 Studi\%20Kualitatif\%20Partisipasi $\% 20$ 
Perempuan \%20dalam\%20Politik.pdf. diakses 06 November 2016, Pada Pukul 20.00 WIB.

BPS, n.d. https://www.bps.go.id/linkTabelStatis/ view/id/983. Terakhir akses 06 November 2016, Pada Pukul 20.00 WIB.

Indonesia Economic Outlook, n.d. http://www. focus-economics.com/countries/indonesia. Terakhir akses 20 Juni 2018, Pada Pukul 20.00 WIB.

WTO.org, 2017. https://www.wto.org/english/ news_e/news17_e/mc11_12dec17_e.htm, terakhir akses 20 Juni 2018 
